\title{
Role of the European Union in Applying the Principles of Subsidiarity and Proportionality
}

\author{
Aulona Haxhiraj \\ PHD Student \\ Pedagogue "Ismail Qemali" University of Vlora \\ aulonahaxhiraj@yahoo.com; phone number 0674029533
}

Doi:10.5901/ajis.2013.v2n8p417

\section{Abstract}

The principle of subsidiarity has always been the subject of many studies for the fact that the center of gravity moves gradually from the criteria of attribution to those relating to the exercise of powers. The principle of subsidiarity involves only European Union's competitive or collaborative competences when the action cannot be accomplished in member states level. While the principle of proportionality is a principle which obliges EU institutions to control the exercise of powers so that the measures taken do not exceed what is necessary to achieve the objectives that the institution or the institution must comply. The European Union institutions operate through political mechanisms (ex ante) and law mechanisms (ex post) control of the two principles.Legal control represents the fact that the Court of Justice has been cautioned in its control activities. The political control, in this paper, serves to present an overview of what led the recent treaties. In particular, we will analyze a new mechanism of preventive control, which aims to strengthen the control of the principles by the state parliaments (early warning system) on the basis of subsidiarity, which is a direct instrument to influence the legislative process. States are informed of any initiative of the Commission, who is forced to reconsider his proposal if one third of national parliaments consider incompatible with the principle of subsidiarity.

Keywords: Unione europea, il principio di sussidiarietà, proporzionalità, visite ispettive, il controllo di diritto politico.

\section{Introduction}

European Union institutions have been given a precise role for the compliance and implementation of the principles of subsidiarity and proportionality, which are defined in the Article 3B of the Treaty of Maastricht [1]. The competences of European Union are determined in terms that need to be achieved rather than in fields that need to be disciplined. Related to this there is not a catalog of the sectors assigned to the responsibility of European Union.

The principle of subsidarity in a progressive manner is determined from the juridical science as a social and lawful, according to which the intervention of public authorities, towards the citizens or authorities, must be applied only as a help in cases when a the citizen or the primal subject is incapable to act itself [2]. Subsidarity involves only European Union's competitive or collaborative competences with member states. All the functions which are not expressly attributed, from Treaties, to European Union or member states are competitive. The principle of Subsidarity is called for action in case these two criteria are met [3]:

1. The action of European Union results more efficient than that undertaken in member states level and this seen in terms of dimensions and effects.

2. The objectives cannot be accomplished only by actions of member states.

The principle of proportionality is presented as a flexible concept, which is established on a ratio determined by the elements that it is composed. A concept and a legal standard known and applied, which was released by the Court Justice and rose to the rank of a primary principle. Proportionality principle is reconstructed as a tool that allows verification of the legitimacy of the relationship between the means used and the objectives to be achieved by the EU. The content and form of the action does not exceed what is necessary to achieve the objectives set by the Treaties

This principle requires that the measures imposed by the states and the EU institutions are adequate in achieving the objectives to be pursued and not to exceed the limits more than what it is necessary. The citizens, on the basis of this principle, are required to be imposed only obligations strictly necessary to achieve the public interest by authorizing a supreme control over operating autorritetit discretion. The exact definition of public interest pursued as a counterpoint of private interest may be sacrificed in order to legitimate only if there is a proportional relation between the vehicle and the goal is defined as a thing "in which the public, the community at large, has some interest by wich their legal rights or liabilities are affected. It does not mean by matters in questions. The term private interest decribes a legal concern of an 
individual, or the position of being affected by something or a title or a right( in property) or an individual penuciary stake".[4]

There is an evident interconnection between the two principles although they are applied to meet different functions. The function of subsidiarity principle the legitimacy, under certain conditions, in the areas of competitive competences, of European activity instead of the governmental. As to the principle of proportionality, the objective is to measure the intensity of the action itself on the basis of means used towards the objective to be achieved, referring to all the competences that are attributed, either exclusive or competitive.

In this article, we try to will analyze and evaluate the role of the European Union in applying the principles of subsidiarity and proportionality European institutions will examine the application of the principles that discipline.

Council and the European Parliament respect the principles and practice of justifying respect to attributes that are accorded [5]. Control is carried out respecting the principles fixed by normal procedures for review of the Commission's proposals.

To achieve this goal, detailed research will be presented about the preconditions that allowed involving europian institutions in the EU activities and historical background of the rights that europian institutions had before the Lisbon Treaty came into force.

In order to achieve this objective, historical, logical, analytical and comparative methods are used.

\section{The role and the self-discipline of the EU institutions towards compliance of principle of subsidiarity}

Being in possession of the right of normative acts proposal, the Commission has been the first European institution has argued the necessity of actions at European level, in addition to those at member states level. To ensure a correct appliance of the principle of subsidiarity, the Commission, since November 1993, has really taken the task to motivate all legislative proposals and also to review the in use legislation. [6]

Mechanisms to monitor the principle of subsidiarity provided for compliance with certain obligations during the actual drafting of legislation. Thus, before proposing legislative acts, the Commission must prepare a Green Paper. Green Papers consist of wide-ranging consultations. They enable the Commission to collect opinions from national and local institutions and from civil society on the desirability of a legislative proposal, in particular in respect of the principle of subsidiarity. The Commission presents to the European Council and the Parliament an annual report on the implementation of the principle of subsidiarity. The Council and the European Parliament must respect and comply with the principle of subsidiarity, and to justify the compliance through the exercise of the attributes accorded to them [7]. The control of the compliance of such a principle is done under fixed procedures for the review of the Commission's proposals. In fact, the British request to establish a preventive control to respect the principle of subsidiarity is not accepted.

Any Member State may request to include the review of a following proposal in the Council section temporary agenda. [8]The Parliament and The Council must justify the conformity with the principle of subsidiarity of any modification done in text proposed by the Commission.

The Treaty of Lisbon innovates by associating national Parliaments closely with the monitoring of the principle of subsidiarity. National Parliaments now exercise twofold monitoring:

- they have a right to object when legislation is drafted.

- through their Member State, they may contest a legislative act before the Court of Justice of the EU if they consider that the principle of subsidiarity has not been observed.[9]

Under the Lisbon Treaty, the ex ante monitoring role of the national parliaments has been strengthened as regards control over the subsidiarity principle (but not the proportionality principle, which monitors that the draft legislative act does not go beyond what is necessary).

The European Parliament, the Council and the Commission, and, where appropriate, the group of Member States, the Court of Justice, the European Central Bank or the European Investment Bank, if the draft legislative act originates from them, shall take account of the reasoned opinions issued by national parliaments or by a Chamber of a national parliament. Each national parliament shall have two votes, shared out on the basis of the national parliamentary system. In the case of a bicameral Parliamentary system, each of the two Chambers shall have one vote [10]

The first round takes place exclusively between the Commission and the chambers of nation parliaments. It is only after that reading that the Commission submits the possibly revised proposal to the ordinary legislative process. Those parliaments which have drafted a negative position have the possibility to take legal action against the Commission on the grounds of an infringement of the subsidiarity principle. The legal process takes place in the European Court of 
Justice.

The effective use of the mechanism depends not only on institutional arrangements but on the self-perception of parliaments regarding their scrutiny role vis-à-vis the executive and the EU institutions.

The Treaty of Lisbon also associates the Committee of the Regions with the monitoring of the principle of subsidiarity. In the same way as national Parliaments, the Committee may also contest, before the Court of Justice of the EU, a legislative act that does not comply with the principle of subsidiarity.

The decision-making process capacity of European politics to ensure that decisions are taken as close to citizens as possible can be daubted for the observance of the limits set by the principle of subsidiarity towards the intervention of the European institutions. The role assigned to the Council in the European decision-making process is not sufficient to ensure the correct appliance of Article 3B. Thus we can say the same the role of the Committee of the Regions and the European Parliament. The consultation of the first one, even when it is compulsory by the Treaty, is never binding, because of the fact that none can prevent the Council to adopt measures which the Committee of the Regions finds incompatible with Article 3B, second paragraph. With regard to the European Parliament, the influence that this institution can exercise taking a decision about a action is somehow limited.

In areas where the European Parliament can reverse the common position adopted by the Council only by an absolute majority of its members, the power to reject the common position adopted by the Council, allows the Parliament to oppose the adoption of European laws as incompatible in each profile with the principle of subsidiarity, showing very drastic instrument, taking into account the required majority. It is also difficult to imagine that the European Parliament is shown as a defender of the prerogatives of national parliaments. Despite the appeals for a closer collaboration [11], the connections between the first, protector of the European democratic legitimacy, and the second, an expression of popular legitimacy, are characterized by certain emulation.

To ensure the compliance for the principle of subsidiarity, it was not considered up to the mark in order to control the national parliaments and, in some agenda, local authorities exercise on the behavior of governments in front of the Council, the role of working groups composed of representatives of national administrations allow state executives to put out of watch of the respective parliaments and the accountability that follows them. Left in the institutional autonomy of Member States, the powers assigned to assemblies and to the local authorities on the position of the governments in the legislative process, to vary in depth from system to system.

\section{The role of institutions for the principle of proportionality control.}

The principle of proportionality has a dual function: protects national interests against EU intervention limiting it in the actions that are necessary achieve the objectives assigned to it, and as a general principle of law regulates the interference of political institutions in the sphere of individual autonomy. The application of the principle of proportionality operates in order to the principle of legality throughout the European system. For this we must emphasize that this principle of respect put exact proportion between the goals to be achieved and the means used by the European institutions and Member States: sanctions in the right proportion between the violation of the law and punishment is the realization of authority. This brings the obligation to give priority to the vehicle that delivers the least possible infringement of the liberties guaranteed by the Treaties.

The achievement of the objectives followed by the principle of proportionality is performed due to internal self regulating mechanisms and there are applied the same procedures and measures used for the principle of subsidiarity. To ensure the observance of the principle of proportionality the control of each of the national parliaments serves. Influence over Executive on the decision-making process is not assigned only to European member states and even these often limit theirselves from providing advisory opinions. Member States are limited in the process from the composition and the role of the Council in the decision-making process. Also, there is a low transparency in the work of the Council and in the role of working groups composed of ministerial officials. The separation on national basis of Parliament sessions and the consultation of the Committee of Regions are another reason for not guaranteeing in the interests of national normative authority.

The adjustment the interests of national normative authorities for a European action in accordance with the principle of proportionality cannot be entrusted to the intervention of the Committee of the Regions or to the European Parliament. Consultation of the first, is not binding while the influence of the European Parliament exercises over the determination of an action is mandatory, in areas subject to the consultation procedure, of cooperation and codecision.

Even the interest of individuals to avoid interference of the institutions in the sphere of individual autonomy does not find, in political decision-making process of the EU, no tutelim. 


\section{The control for the observance of the principle of subsidiarity.}

The inability of European normative process to ensure due to internal self regulating mechanisms, the spontaneity of observation of the principle of subsidiarity, imposes to entrust the task of controlling the observance of this principle to the European jurisprudence. What remains "to be discussed" is this level of this control. There are different attitudes from the Doctrine but it is generally accepted that this cannot be a partial judgment. In support of such a conclusion the principle of subsidiarity is called. Because of the flexible nature and its formulation, this principle would refer to European political institutions a wider discretionary in the intervention decision of $\mathrm{EU}$ in the sector of competitive competences.

This control is an ex post judicial control and a violation of this principle can be put under any recourse to the Court of Justice: recourse in the absence, trial delay, and recourse for cancellation or excess of power. But not all of these procedural instruments are presented in the same manner for use. In fact, it seems unthinkable that the Court sentences the Commission or the Council, by the recourse in the absence, for not issuing a specific act. However, in all the cases into consideration the control of the Court of Justice should definitely be marginal. It is expressed, in the field of subsidiarity, that it will restrict its task of detecting manifested error cases and of deviation of power, copying the behavior of the German Constitutional Court over the control of this principle.

Luxembourg judges take measures for the attenuation of the proportionality control that they exercise themselves on national legislations in the field of manufacturing and trading of goods. National dispositions which explain the most important effects on imported European products to be acceptable only if it is necessary to satisfy the imperative needs and proportionate closely with such a purpose. The Court goes on the line by doing so, on questions ask for the principle of proportionality. [12]

Legitimate entities to set up a canceling recourse because of the violation of the principle of subsidiarity are the Member States, the Council and the Commission, and under certain circumstances the European Parliament and the European Central Bank [13]. The problem of legitimacy to act towards violations of the principle in question belongs essentially to small territorial entities and, in particular, to the Committee of the Regions. The latter has been denied of procedural legitimacy from the Court on the basis of the Treaty KEKC, since it has to do with unincorporated entities, in its judgment, on the list of the legitimates to run, contained in the Treaty. Analogous problems do not arise in the EC Treaty, which explicitly recognizes the active procedural legitimacy to " any natural or legal person against decisions taken towards them". Regions as much as the Committee may demonstrate 'their interest to act', assuming a less favorable procedural role against the one which is provided to the previous mentioned entities.

\section{The control for the observance of the principle of proportionality.}

The assurance of the control of the principle of proportionality, since there is a lack of internal self regulating mechanisms in political decision-making process, there remains only to rely on the Court of Justice as task to ensure its adherence.

Control over the application of the principle of proportionality in the European system intends to correct the results of a not conceived decision-making process, in structure and content. EU performs an intervention limited to what is necessary to achieve the goals predicted by the Treaty, as a general principle of the right and of interest to stop the interference of the institutions in the sphere of individual autonomies.

The Court of Justice is being engaged, since the 60 s, to fight against the paralysis of European decision-making process. By the mid-80s the jurisprudence of the Court entered a stage of evolution, relieving the pressure on national governments through an expansive interpretation. [14] This court requires deceleration of the control over observance of proportionality especially on national legislation in the field of the trading of goods. Although the State dispositions are applicable without exception, they specify the most significant effects on imported products, continue to be declared acceptable only if it is absolutely necessary to satisfy imperative interests and strictly proportionate to such a purpose.

The slowdown in the jurisprudence ever the free movement of goods in control of proportionality influences in the free movement of services. With the difference that in this sector the application of a minimum standard of proportionality belongs to the national discriminatory or not applicable rules.

As we have repeatedly affirmed the EU's powers are described in terms of objectives to be achieved and of necessary means, opportunistic, imposing to the EU the not excessing in choosing of the measures to be adopted, as necessary for achievement of the objectives set. In another sense of the direct norm for the regulation of the individual autonomy against weakening of the interventions by the institutions, the principle of proportionality determination becomes part of the determination of the jurisprudence of the Court of Justice, of the basic unwritten principles of European rank. From the essential role played by the above mentioned principle, in the scene of judgment on the 
respecting of human rights as much as the fundamental freedoms of the unique market, we have seen significant footprints in European jurisprudence. The Court of Justice sets to a similar principle, among the restrictions of exercising the human rights set by political institutions in general interest, those limitations that, considering the objective to achieve, are interpreted into a disproportionate and unacceptable intervention, damaging the essence of those rights.

The control over appropriateness of measures towards their assigned objective occupies a very important place. First of all, the legitimacy of the measures is not subject to the story, based on an ex post evaluation, their specific effectiveness: it is sufficient, that based on an ex ante control, aligned with the actual situation at the time of its declaration, the act cannot be called inadequate to achieve the goal that is set. But neither action is required in order for the mass to achieve the intended purpose: it is satisfactory that it contributes in any way to follow the objective. Finally, in many sectors that are European competence, such as agricultural policy, transport, harmonization of national legislation and social policy, Court of Justice and the Court of the First Instance, recognized to the European institutions an exercise side field, for the content of the measures that it will adopt, limiting only in sanctioning of evidently incapable measures to achieve the needed objectives.

Just like the control over the appropriateness of the act with the purpose, the control over the necessity of the measures taken to achieve the objective is developed in the European Union level too. In fact, there are no exceptions missing to the rule, which are present especially in the sector of sanctions and European dispositions for the unfavorable legal effects for the economic operators and for non-compliance the obligations settled by them.

Only manifested disproportion from the act towards the goal to achieve may contest the validity of the measures adopted by it. It results difficult to criticize the care for the verification procedure of suitability, the necessity and equality of the adopted measures by the European legislator. Numerous factors contribute justification to the slowdown of the degree of judgment that is recorded in the control of jurisprudence from political institutions, from each component of the principle of proportionality.

Thus, the application of a suitability test based on an ex ante evaluation of the efficiency of measures in relation to the aim pursued responds to the need to be recognized by the European legislator, the margin of error, despite when it comes to to predict the future effects and the uncertain interventions.

\section{Conclusions}

Despite their different functions, both principles subsidiarity and proportionality, from the jurisprudence of the European is deduced that the disrespect for the first one can automatically lead to an impairment of the other one. It appears evident, the attribution of the obligations and disproportionate benefits in a category of individuals, putting in a right and more a privileged position or not eligible entities included by it.

Application of the principle of subsidiarity provides a wide margin discretionarily. Evaluations brought for the application show that this principle has a political sense, acting as a guide for institutions and states, in determining the level most appropriate action to achieve the objectives set. Adjustments made note that probably the interpretative difficulties request perseveringly the need of interpretation of the Court of Justice for the clarification of the respective areas of exclusive competences and competitiveness.

The criteria for determining the competent level to act are not competing with each other. In fact, the European Union called upon to act in a Subsidiary way in the case of the insufficient action of the state or, though being able, the European action results to be greater in efficiency, giving to European institutions a wide margin discretionarily. For this reason there are well defined conditions of application of the principle of subsidiarity.

The system of the separation of powers should find a balance and guarantee point in the political control of the Council and in the jurisdictional control of the Court of Justice. Jurisdictional control mechanisms have not produced the results that were expected, even judges, because of their institutional role, are concerned to favor European integration process, strengthening the prerogatives of the EU and the effectiveness of their legal system.

In this context, the Court's jurisprudence is oriented to interpret broadly the attributes of EU, rather than being limited to the custody of national competence. Until the entry into force of the Treaty of Maastricht there have not been decisions which would notice as illegitimate the acts of the European Union because of violations of competences that to the latter were granted. We have to accept that the rules in the area under consideration are subject to a more political control than a jurisdictional control.

The political control, through a completely new mechanism" Early Warning system " allows national parliaments (or one of the rooms in that case they would be bicameral), to give the motivated opinion on the subject under consideration. The involvement of national parliaments responds to the constitutional need and one of the main indications of the 
Declaration of Leaken. Moreover, by introducing a valuable tool for control the observance for the principles is significantly strengthened. The motivated thinking of the national parliaments should be taken in consideration in case of a negative opinion of one third of them (for some decisions $1 / 4$ ), in such a case the Commission should reconsider the proposal.

However, the Commission is free to confirm its proposal and in this case it would return to a legislative proposal, and national parliaments would not have an autonomous title to contest the legitimacy in front of the Court of Justice. If the critics of national parliaments are not welcomed by the Commission, they may request that their opinions produce effects if $j$ critics are given by the respective Governments, through the Commission or through the jurisdictional recourse ex post. This innovation can be considered a step forward, because it guarantees the specific efficiency of the preliminary review of the national parliaments and strengthens the custody of the principles. But this is not enough.

The Commission must attach to their proposal a file where evaluations should be contained for the principle of subsidiarity and proportionality. Such a file would provide elements that would allow evaluating the financial impact and the respective consequences.

For the implications of the principle of subsidiarity and proportionality, and the ability to forecast a better jurisdictional control (not just political), dispositions are predicted over their application related to the recourse at the Court of Justice.

But, procedural instruments that derive for the institutions do not seem sufficiently precise to accept a sharp intervention from the Court. For the same reason there would be little chances of completing recourse in the absence

The possibility to propose recourses is spread to the Committee of the Regions, but it is conditioned only to certain conditions and not completely regarding the limitation of legislative acts for which it should be consulted. Regions, especially those equipped with legislative power are not recognized their preliminary control mechanism. They can act only through the Committee of Regions.

\section{Notes:}

1. Article 3B of the Treaty of Maastricht says" "The Community shall act within the limits of the powers conferred upon it by this Treaty and of the objectives assigned to it therein. In areas which do not fall within its exclusive competence, the Community shall take action, in accordance with the principle of subsidiary, only if and in so far as the objectives of the proposed action cannot be sufficiently achieved by the Member States and can therefore, by reason of the scale or effects of the proposed action, be better achieved by the Community. Any action by the Community shall not go beyond what is necessary to achieve the objectives of this Treaty."

2. EUROFOCUS, II Principio di sussidiarietà nell'evoluzione giuridica europea.

3. Lisa Cervone, "Principio di sussidiarieta delle system font."

4. Cfr Black's Law dictionary, publication of 1891-1991.

5. Competences defined by Article $138 \mathrm{~B}$ and $152 \mathrm{CE}$.

6. The report of the European Commission addressed to the Commission of Edinburgh, November 1994.

7. Competences defined by Article138B and $152 \mathrm{CE}$

8. Article 2 of the Internal Regulation of the European Council.

9. http://europa.eu/legislation_summaries/institutional_affairs/treaties/lisbon_treaty_en.htm

10. Article 7 of Protocol No 2 Treaty of Lisbon.

11. Written statement on the powers of the European Parliament and on the calling of the general state of the European Parliament of 16 May 1988 (in Guca / C167 of 27 July 1988, page 19) Resolution on relations between the European Parliament and the parliaments of the Member States, adopted on February 16, 1989 (in Guca, C 69 of 20 March 1989, page 149).

12. Decision of March 12, 1987, Case 178/84 Commission v Germany, judgment of 23 Feb 1988, case 216/84, Commission v. France, judgment of 14 July 1988, issue 90/86 penal procedure against the Zoni.

13. Interpretation traditionally used by Cassis de Dijon decision of the $80 \mathrm{~s}$.

14. Article $173 \mathrm{CE}$.

\section{References}

Adriana Garabello, II principio di sussidiarietà nell'evoluzione giuridica europea.

Iva Zajmi, E drejta europiane; Botim i 2007.

Cours d'Institutions européennes. Le puzzle européen. - Jean Luc Sauron 
Niccolai, Delegificazione e principio di competenza, Cedam, Padova, 2001.

Constatinesco, La distribution des pouvoirs entre la Communitè et ses Etas membres: l'équilibre mouvant de la competence legislative et le principe de subsidiarité.

Erjona Canaj, "Principio di sussidiarieta e proprcionalita nell ambito del Unione Europeo".

Rinella, "Osservazioni in ordine alla ripartizione delle competenze tra Comunità europea e Stati membri alla luce del principio di sussidiarietà".

Caretti , "Il principio di sussidiarietà e i suoi riflessi sul piano dell'ordinamento comunitario e dell'ordinamento nazionale".

D'agnolo, La sussidiarietà nell'Unione Europea, Cedam.

S.Cassese ; L'architettura constituzionale della Comunita europea dopo il Trattato di Maastricht.

Inga Daukšiené, Sigita Matijošaitytè, The role of national parliaments in the european union after Treaty of Lisbon, JURISPRUDENCE 2012.

http://europa.europa.it

http://europa.eu/legislation_summaries/institutional

http://www.euroinfocenter.it 